\title{
A COMPARATIVE STUDY OF EFFICACY OF NEBULIZER AND METERED DOSE INHALER WITH SPACER IN THE TREATMENT OF ACUTE ASTHMA IN CHILDREN
}

\author{
Jeyaraman Balasubramanian1, Chelladurai Vasanthamalar², Soundaian Balasankar3, Ganeshapillai Mathevan
}

${ }_{1}^{1}$ Assistant Professor, Department of Paediatrics, Institute of Child Health \& Research Centre, Government Rajaji Hospital, Madurai Medical College, Madurai, Tamilnadu.

${ }^{2}$ Post Graduate, Department of Paediatrics, Institute of Child Health \& Research Centre, Government Rajaji Hospital, Madurai Medical College, Madurai, Tamilnadu.

${ }^{3}$ Professor, Department of Paediatrics, Institute of Child Health \& Research Centre, Government Rajaji Hospital, Madurai Medical College, Madurai, Tamilnadu.

${ }^{4}$ Director, Department of Paediatrics, Institute of Child Health \& Research Centre, Government Rajaji Hospital, Madurai Medical College, Madurai, Tamilnadu.

\section{ABSTRACT}

\section{BACKGROUND}

To compare the relative efficacy of Nebulizer and Metered Dose Inhaler (MDI) with spacer for the administration of aerosolized salbutamol in the treatment of acute asthma.

\section{MATERIALS AND METHODS}

A randomized, prospective, interventional study was conducted on 400 children aged 2-12 years with acute asthmatic attack. The subjects were randomly assigned to two groups for salbutamol administration, Group I was given salbutamol by jet nebulizer and Group II by metered dose inhaler with spacer. Baseline characteristics were recorded (Duration of illness, nature of medi cations, family history, allergy history, etc.). Children were categorized into low, middle and high grade according to clinical asthma score (Based on presence of wheezing, retractions, dyspnoea). Initial assessment was done at zero minutes. Clinical responses were assessed at 20, 40 and 60 minutes' intervals after treatment. Poor response at 60 minutes were considered as treatment failure.

\section{RESULTS}

In low grade, there was no significant difference between both groups. In middle grade, Group II required less number of treatment ( $p$ value $<0.001$ ), which was statistically significant. In high grade also, the ' $p$ ' value is 0.032 and was significant. The overall clinical response among Group I and Group II was statistically significant. There was no statistical significance among the treatment failure in both groups.

\section{CONCLUSION}

MDI with spacer is an effective alternative to nebulizer for the administration of aerosolized drugs in acute asthmatic attack in paediatric emergency department. Use of MDI with spacer is more effective than nebulizer for the treatment of moderate-to-severe asthma. Nebulization has some limitations like inconvenience, slow implementation, high cost, power requirement and uncontrolled particle sizes, but none in case of MDI.

\section{KEYWORDS}

Nebulizer, Metered Dose Inhaler, Acute Asthma.

HOW TO CITE THIS ARTICLE: Balasubramanian J, Vasanthamalar C, Balasankar S, et al. A comparative study of efficacy of nebulizer and metered dose inhaler with spacer in the treatment of acute asthma in children. J. Evolution Med. Dent. Sci. 2016;5(39): 2367-2371, DOI: $10.14260 /$ jemds/2016/550

\section{INTRODUCTION}

Many consensus protocols and guidelines have been published for improving the treatment of asthma. The first line of treatment is inhaled beta- 2 agonist (Salbutamol). In general, beta- 2 agonist administered via Nebulizer is the standard treatment for asthma exacerbations. ${ }^{1}$ But there are some limitations in nebulization like power requirement, equipment failure, maintenance charges, some children may not tolerate

Financial or Other, Competing Interest: None.

Submission 19-03-2016, Peer Review 24-04-2016,

Acceptance 30-04-2016, Published 13-05-2016.

Corresponding Author:

Dr. Jeyaraman Balasubramanian,

Assistant Professor,

Department of Paediatrics,

Institute of Child Health \& Research Centre,

Government Rajaji Hospital,

Madurai-625020,

Tamilnadu.

E-mail: drbaladch@yahoo.co.in

DOI: $10.14260 /$ jemds $/ 2016 / 550$ noisy equipment. Metered Dose Inhaler (MDI), which is small and portable have advantages over nebulizer. Guidelines from GINA recommend MDI for children with asthma due to increased efficacy and decreased cost.(2)

This study was conducted to compare the relative efficacy of MDI with spacer and nebulizer for the administration of aerosolized salbutamol in the treatment of acute asthma in children.

\section{AIM OF THE STUDY}

To compare the relative efficacy of Metered Dose Inhaler (MDI) with spacer and Nebulizer for the administration of aerosolized salbutamol in the treatment of acute asthma.

\section{MATERIALS AND METHODS \\ Setting}

This study was done at Institute of Child Health and Research Centre, Government Rajaji Hospital, Madurai.

\section{Study Period}

One year from September 2012 to August 2013. 


\section{Study Design}

Randomized, interventional study.

\section{Inclusion Criteria}

Children aged 2-12 years with acute asthmatic attack, irrespective of the previous treatment.

\section{Exclusion Criteria}

Children diagnosed as having concurrent pneumonia, chronic lung disease, cyanotic congenital heart disease, suspected foreign body aspiration, very sick requiring intensive care.

\section{Ethical Clearance}

Obtained from Ethical Committee, Madurai Medical College and Government Rajaji Hospital, Madurai.

\section{METHODOLOGY}

Informed consent was obtained from the parent/guardian for the intervention.

\section{A Special Proforma was Designed to Record the following Information}

- Demographic data.

- Onset of first episode and frequency of symptoms.

- Family history.

- Allergic history.

- Clinical asthma score.

The cases were enrolled in group I or group II by randomization. Block randomization was done using the software SAS 9.1.

Children were administered aerosolized Salbutamol. Group I was given by Jet Nebulizer and Group II by MDI with spacer.

For Nebulization, $0.15 \mathrm{mg} / \mathrm{kg}$ (Max $2.5 \mathrm{mg}$ ) of salbutamol diluted in $2.5 \mathrm{~mL}$ Normal Saline was administered through nebulizer.

For metered dose inhaler, 4 puffs for $<6$ years and 8 puffs for $>6$ years ( 1 puff delivering $100 \mathrm{ug}$ ) was administered with spacer with or without mask. Spacer with a volume of $750 \mathrm{~mL}$ with one-way valve was used. Face mask attachment was required in younger (Less than 3 years) children. Initial assessment was done at zero minutes by clinical asthma score.

\begin{tabular}{|c|c|c|c|}
\hline Score & Wheeze & Retraction & Dyspnoea \\
\hline 0 & No Wheeze & No Retraction & No Dyspnoea \\
\hline 1 & End Expiratory & Intercostal Retraction & Normal Activity \\
\hline 2 & $\begin{array}{c}\text { Inspiratory \& } \\
\text { Expiratory }\end{array}$ & $\begin{array}{c}\text { Intercostal/Suprasternal } \\
\text { Retraction }\end{array}$ & $5-8$ Words \\
\hline 3 & Audible/Silent & Nasal Flare & $\begin{array}{c}\text { Not Speaking } \\
\text { Sentence }\end{array}$ \\
\hline
\end{tabular}

Total score-9 (Wheeze-3, Retraction-3, Dyspnoea-3).

The cases are graded as below according to their score:

Low : $0-2$

Middle: $\quad 3-6$

High : 7-9
Clinical responses were assessed at 20, 40 and 60 minutes' intervals by an assessor who was not aware to which group the patient belongs. Poor response at 60 minutes were considered as treatment failure.

\section{Statistical Analysis}

All data were entered in Excel 2007 and statistical analysis was performed using the statistical software SPSS 16.0. For all categorical variables, Pearson Chi square test and Fisher's exact test were used and for non-parametric data, Mann Whitney U test was used.

' $p$ ' value less than 0.05 is considered to be statistically significant.

\section{Randomization}

Out of total 400 cases, 200 were in Group I and 200 were in Group II as divided by a computer generated sequence.

\section{Age Distribution}

Out of 400 cases, $65 \%(n=260)$ were below 6 years and $35 \%$ $(n=140)$ were above 6 years.

\section{Sex Distribution}

Out of 400 cases, $59 \%(n=235)$ were males and $41 \%(n=165)$ were females. Male:Female ratio is 1.42:1.

\section{Family History}

Out of 400 cases, $46.3 \%(n=185)$ had positive family history; 89 cases $(48 \%)$ in nebulizer group, 96 cases (52\%) in MDI group.

\section{Allergic History}

Out of total 400 cases, $22.8 \%$ (n=91) had allergic history. 40 cases $(44 \%)$ in nebulizer group, 51 cases $(56 \%)$ in MDI group.

\section{Previous Treatment History}

Out of 400 cases, 376 cases (94\%) had previous history of treatment in the form of oral medications, injection and inhalation, 202 cases (54\%) in nebulizer group and 174 cases (46\%) in MDI group, but nobody was on regular medications. (We used to get such type of patients only in our hospital) Remaining 24 cases (6\%) came with first attack of wheezing.

In our study, there is no statistical significance among age and mode of treatment $(p=0.098)$, sex and mode of treatment $(p=0.761)$, positive family history and mode of treatment $(p=0.483)$, presence of allergic history and mode of treatment $(\mathrm{p}=0.074)$.

\begin{tabular}{|c|c|c|}
\hline & Group-I & Group-II \\
\hline Low & $49(24.5 \%)$ & $43(21.5 \%)$ \\
\hline Middle & $104(52 \%)$ & $106(53 \%)$ \\
\hline High & $47(23.5 \%)$ & $51(25.5 \%)$ \\
\hline Total & $\mathbf{2 0 0 ( 1 0 0 \% )}$ & $\mathbf{2 0 0}(\mathbf{1 0 0} \%)$ \\
\hline \multicolumn{3}{|c|}{ Table 1: Grading of Severity } \\
\hline
\end{tabular}

Group I and II were graded on the basis of clinical Asthma score into low, middle and high grade. 
Number of Doses Vs Mode of Treatment (Low Grade)

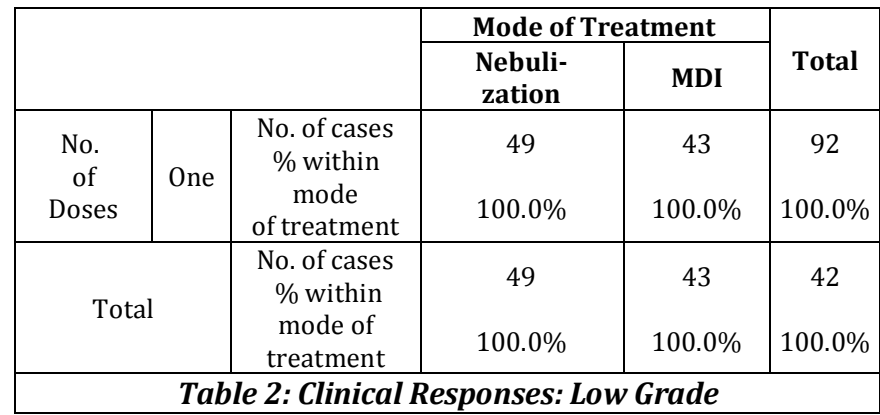

Hence, in low grade, no difference in clinical response between both the groups.

Number of Doses Vs Mode of Treatment (Middle Grade) $-(p=0.001)$.

\begin{tabular}{|c|c|c|c|c|c|}
\hline & \multicolumn{2}{|c|}{ Mode of Treatment } & \multirow{2}{*}{ Total } \\
\hline & & & Nebulization & MDI & \\
\hline \multirow{3}{*}{$\begin{array}{c}\text { Number } \\
\text { Of } \\
\text { Doses }\end{array}$} & One & $\begin{array}{c}\text { No. of cases } \\
\% \text { within mode } \\
\text { of treatment }\end{array}$ & $\begin{array}{c}79 \\
76.0 \% \\
\end{array}$ & $\begin{array}{c}100 \\
94.3 \%\end{array}$ & $\begin{array}{c}179 \\
85.2 \% \\
\end{array}$ \\
\hline & Two & $\begin{array}{c}\text { No. of cases } \\
\% \text { within mode } \\
\text { of treatment }\end{array}$ & $\begin{array}{c}23 \\
22.1 \% \\
\end{array}$ & $\begin{array}{c}6 \\
5.7 \% \\
\end{array}$ & $\begin{array}{c}29 \\
13.8 \% \\
\end{array}$ \\
\hline & Three & $\begin{array}{c}\text { No. of cases } \\
\% \text { within mode } \\
\text { of treatment }\end{array}$ & $\begin{array}{c}2 \\
1.9 \% \\
\end{array}$ & & $\begin{array}{c}2 \\
1.0 \% \\
\end{array}$ \\
\hline \multicolumn{2}{|c|}{ Total } & $\begin{array}{l}\text { No. of cases } \\
\% \text { within mode } \\
\text { of treatment }\end{array}$ & $\begin{array}{c}104 \\
100.0 \%\end{array}$ & $\begin{array}{c}106 \\
100.0 \%\end{array}$ & $\begin{array}{c}210 \\
100.0 \%\end{array}$ \\
\hline \multicolumn{6}{|c|}{ Table 3: Clinical Responses: Middle Grade } \\
\hline
\end{tabular}

There is significant statistical difference between 2 groups $(\mathrm{p}=0.001)$.

In middle grade, clinical response to MDI with spacer is better than nebulizer.

Number of Doses Vs Mode of Treatment (High Grade) $(\mathrm{p}=0.032)$.

\begin{tabular}{|c|c|c|c|c|c|}
\hline & \multicolumn{2}{|c|}{ Mode of Treatment } & \multirow{2}{*}{ Total } \\
\hline & & & Nebulization & MDI & \\
\hline \multirow{4}{*}{$\begin{array}{c}\text { No. } \\
\text { of } \\
\text { Doses }\end{array}$} & One & $\begin{array}{l}\text { No. of cases } \\
\% \text { within } \\
\text { mode of } \\
\text { treatment }\end{array}$ & $\begin{array}{c}10 \\
21.3 \%\end{array}$ & $\begin{array}{c}22 \\
43.1 \% \\
\end{array}$ & $\begin{array}{c}32 \\
32.7 \% \\
\end{array}$ \\
\hline & Two & $\begin{array}{c}\text { No. of cases } \\
\% \text { within } \\
\text { mode of } \\
\text { treatment }\end{array}$ & $\begin{array}{c}17 \\
36.2 \% \\
\end{array}$ & $\begin{array}{c}20 \\
39.2 \% \\
\end{array}$ & $\begin{array}{c}37 \\
37.8 \% \\
\end{array}$ \\
\hline & Three & $\begin{array}{c}\text { No. of cases } \\
\% \text { within } \\
\text { mode of } \\
\text { treatment }\end{array}$ & $\begin{array}{c}8 \\
17.0 \%\end{array}$ & $\begin{array}{c}4 \\
7.8 \% \\
\end{array}$ & $\begin{array}{c}12 \\
12.2 \%\end{array}$ \\
\hline & $\begin{array}{c}\text { Treatment } \\
\text { Failure }\end{array}$ & $\begin{array}{c}\text { No. of cases } \\
\% \text { within } \\
\text { mode of } \\
\text { treatment }\end{array}$ & $\begin{array}{c}12 \\
25.5 \% \\
\end{array}$ & $\begin{array}{c}5 \\
9.8 \%\end{array}$ & $\begin{array}{c}17 \\
17.3 \% \\
\end{array}$ \\
\hline \multicolumn{2}{|r|}{ Total } & $\begin{array}{c}\text { No. of cases } \\
\% \text { within } \\
\text { mode of } \\
\text { treatment }\end{array}$ & $\begin{array}{c}47 \\
100.0 \%\end{array}$ & $\begin{array}{c}51 \\
100.0 \%\end{array}$ & $\begin{array}{c}98 \\
100.0 \%\end{array}$ \\
\hline \multicolumn{6}{|c|}{ Table 4: Clinical Responses: High Grade } \\
\hline
\end{tabular}

In high grade, clinical response to MDI with spacer is better than nebulizer. Failure rate is more in nebulizer group than in MDI with spacer group. There is statistical significance among high grade $(\mathrm{p}=0.032)$.
Number of Doses Vs Mode of Treatment ( $p=0.013)$

\begin{tabular}{|c|c|c|c|c|c|}
\hline & \multicolumn{2}{|c|}{ Mode of Treatment } & \multirow{2}{*}{ Total } \\
\hline & & & Nebulization & MDI & \\
\hline \multirow{4}{*}{$\begin{array}{c}\text { No. } \\
\text { of } \\
\text { Doses }\end{array}$} & One & $\begin{array}{c}\text { No. of } \\
\text { cases } \\
\% \text { within } \\
\text { mode of } \\
\text { treatment }\end{array}$ & $69.0 \%$ & $82.5 \%$ & $\begin{array}{c}303 \\
75.8 \%\end{array}$ \\
\hline & Two & $\begin{array}{c}\text { No. of } \\
\text { cases } \\
\% \text { within } \\
\text { mode of } \\
\text { treatment }\end{array}$ & $20.0 \%$ & $13.0 \%$ & $\begin{array}{c}66 \\
16.5 \%\end{array}$ \\
\hline & Three & $\begin{array}{c}\text { No. of } \\
\text { cases } \\
\% \text { within } \\
\text { mode of } \\
\text { treatment }\end{array}$ & $5.0 \%$ & $2.0 \%$ & $\begin{array}{c}14 \\
3.5 \%\end{array}$ \\
\hline & $\begin{array}{l}\text { Treat- } \\
\text { ment } \\
\text { Failure }\end{array}$ & $\begin{array}{c}\text { No. of } \\
\text { cases } \\
\% \text { within } \\
\text { mode of } \\
\text { treatment }\end{array}$ & $6.0 \%$ & $2.5 \%$ & $4.3 \%$ \\
\hline \multicolumn{2}{|c|}{ Total } & $\begin{array}{c}\text { No. of } \\
\text { cases } \\
\% \text { within } \\
\text { mode of } \\
\text { treatment }\end{array}$ & $100.0 \%$ & $100.0 \%$ & $\begin{array}{c}400 \\
100.0 \%\end{array}$ \\
\hline \multicolumn{6}{|c|}{ Table 5: Overall Responses } \\
\hline
\end{tabular}

The overall clinical responses among Group I and Group II is statistically significant $(\mathrm{p}=0.013)$. MDI with spacer is better than nebulizer in all grades of severity.

\section{Treatment Failure}

\begin{tabular}{|c|c|c|}
\hline & Group I & Group II \\
\hline \multirow{2}{*}{ Improved Cases } & 188 & 195 \\
& $94.0 \%$ & $97.5 \%$ \\
\hline \multirow{2}{*}{ Treatment Failure } & 12 & 5 \\
& $6.0 \%$ & $2.5 \%$ \\
\hline \multirow{2}{*}{ Total } & $\mathbf{2 0 0}$ & $\mathbf{2 0 0}$ \\
& $\mathbf{1 0 0} \%$ & $\mathbf{1 0 0} \%$ \\
\hline
\end{tabular}

Here, the 'p' value is 0.083 and is not statistically significant.

\section{DISCUSSION}

\section{Age Distribution}

In our study, out of 400 cases $65 \%(n=260)$ were less than 6 years and $35 \%(n=140)$ were above 6 years. Mean age in our study was 3 years. This was similar to Carlos Rodrigo et al study, in which the average age was 33.1 months.

\section{Sex Distribution}

Out of 400 cases, $58 \%(n=235)$ were males and $41 \%(n=165)$ were females. This was similar to Chalerat Direcwatanachai et al study, in which $65 \%$ were males and $35 \%$ were females. Male children outnumber female.

\section{Family History}

Of 400 cases, $46.3 \%(n=185)$ had positive family history. This was similar to Bijanzadeh Matdi et al study conducted at Department of Paediatrics, Mysore Medical College and Research Institute, Mysore, in which $44.5 \%$ of cases had positive family history. 


\section{Allergic History}

Out of total 400 cases, $22.8 \%(n=91)$ had allergic history. Studies show that those children with asthma more often have allergic history.

\section{Grading of Severity}

In our study on the basis of clinical Asthma score in Group I, $24.5 \%, 52 \%, 23.5 \%$ constituted low, middle and high grade respectively. In Group II $21.5 \%, 53 \%$ and $25.5 \%$ constituted low, middle and high grade respectively. This was similar to Syed Waseem Jamalvi et al study conducted at Agakhan University Hospital, Karachi.(3) In that study, 23.8\% and $24.2 \%$ represented mild-to-moderate asthma in Group A and Group B using Medical Scoring system. This was also similar to Vandana Batra et al study done at Maulana Azad Medical College, New Delhi.(4)

\section{Clinical Responses}

Initial assessment was done for all children at 0 minutes. Clinical responses were assessed for both groups at 20,40 and 60 minutes. Number of treatment required was taken into account. In Low grade, there are 49 cases in Group I and 43 cases in Group II. All cases in both groups required one treatment. There was no statistical difference between both groups. In Middle grade of the total 104 cases in Group I 76\% $(n=79)$ required treatment once, $22.1 \%$ cases $(n=23)$ required twice and $1.9 \%(\mathrm{n}=2)$ required thrice. In Group II, of the 106 cases $94.3 \%(n=100)$ cases required one treatment and $5.7 \%$ $(n=6)$ required two treatments and none of them required third treatment. Here, the $p$ value $=0.001$ which was statistically significant. In High grade, of the total 47 cases in Group I $21.3 \%(n=10)$ cases required treatment once, $36.2 \%$ $(\mathrm{n}=17)$ required twice, $17 \%(\mathrm{n}=8)$ required thrice and $25.5 \%$ $(\mathrm{n}=12)$ were considered treatment failure. In Group II, of 51 cases $43.1(\mathrm{n}=22)$ cases required treatment once, 39.2\% $(n=20)$ required twice, $7.8 \%(n=4)$ required thrice and $9.8 \%$ $(n=5)$ were considered treatment failure.

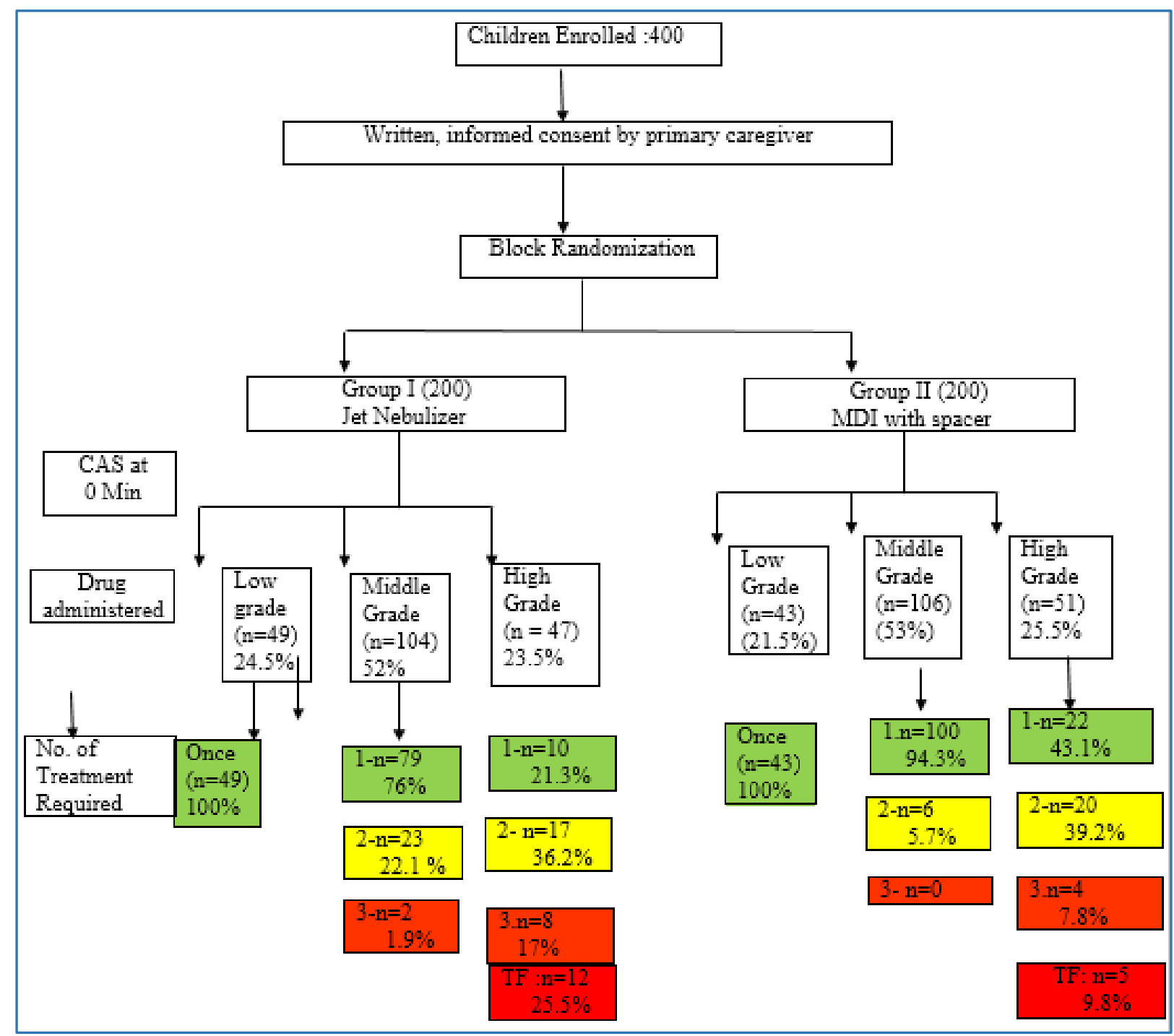

Fig. 1: The Flowchart for Randomization, Intervention and Assessment CAS-Clinical Asthma Score, MDI-Metered Dose Inhaler, TF-Treatment Failure 


\section{Overall Responses}

The overall clinical responses of all the 200 cases in each group was as follows: In Group I, out of 200 cases 69\% ( $n=138)$ required one dose, $20 \%(n=40)$ required two doses and $10 \%$ $(n=5)$ required three doses. In Group II, out of 200 cases $82.5 \%$ $(n=165)$ required one dose, $13 \%(n=26)$ required two doses and $2 \%(n=2)$ required three doses. This was compared against the variables given by Chalerat et al study.(5) Comparison between our study and Chalerat et al study.(5)

\begin{tabular}{|c|c|c|c|c|}
\hline \multirow[b]{2}{*}{$\begin{array}{l}\text { No. of } \\
\text { Doses }\end{array}$} & \multicolumn{2}{|c|}{ Our Study } & \multicolumn{2}{|c|}{ Chalerat et al } \\
\hline & $\begin{array}{c}\text { Gr. I } \\
(n=200)\end{array}$ & $\begin{array}{c}\text { Gr. II } \\
(n=200)\end{array}$ & $\begin{array}{c}\text { Nebulizer } \\
(n=77)\end{array}$ & $\begin{array}{c}\text { MDI with } \\
\text { Volumatic } \\
(n=68)\end{array}$ \\
\hline One dose & 69 & 82.5 & 59.7 & 47.1 \\
\hline Two doses & 20 & 13 & 15.6 & 20.6 \\
\hline Three doses & 5 & 2 & 3.9 & 4.4 \\
\hline
\end{tabular}

\section{Treatment Failure}

At the end of 60 minutes, if there was no clinical improvement they were considered as treatment failure.

In our study, in Group I and Group II, 6\% (n=12) and $2.5 \%(n=5)$ respectively were considered treatment failure.

The following is the number of treatment failure cases in various studies.

\begin{tabular}{|c|c|c|}
\hline & Nebulizer (\%) & MDI (\%) \\
\hline Our Study & 6 & 2.5 \\
\hline Chalerat et al(5) & 2.6 & 1.5 \\
\hline Syed Waseem et al(3) & 10.6 & 4.8 \\
\hline
\end{tabular}

\section{CONCLUSION}

1. MDI with spacer is an effective alternative to Nebulizer for the administration of salbutamol in acute asthmatic attack in paediatric emergency department.

2. Due to the economic and power requirement constraints, MDI with spacer is strongly recommended than nebulizer.

3. Use of MDI with spacer is even more effective than nebulizer in moderate-to-severe asthma.

\section{RECOMMENDATIONS}

MDI with spacer can replace nebulizer for the treatment of acute asthma, both in hospital and in household.

\section{REFERENCES}

1. Robert M Kliegman, Bonita MD Stanton, Joseph St Geme, et al. Nelson text book of paediatrics. Elsevier Saunders 2011;19 th edn.

2. Global strategy for asthma management and prevention. Global Initiative for Asthma (GINA) 2006. Available at http://ginasthma.org.

3. Syed Waseem Jamalvi, Syed Jamal Raza, Farah Naz, et al. Management of acute asthma in children using metered dose inhaler and small volume nebulizer. JPMA 2006;56(12):595-9.

4. Vandana Batra, Sethi GR, Sachdev HP. Comparative efficacy of jet nebulizer and metered dose inhaler with spacer device in the treatment of acute asthma. Indian paediatrics 1997;34(6):497-503.

5. Chalerat Direkwatanachai, Teeratakulpisarn J, Suntornlohanakul S, et al. Comparison of salbutamol efficacy in children- via the metered-dose inhaler (MDI) with volumatic $®$ spacer and via the dry powder inhaler, easyhaler ${ }^{\circledR}$, with the nebulizer-in mild to moderate asthma exacerbation: a multicenter, randomized study. Asian Pac J Allergy Immunol 2011;29(1):25-33. 